Dean Miller

University of Rochester

Chicago, USA

\title{
COLOURS OF GLORY, COLOURS OF TRICKERY: HERO AND HIS OPPOSITE IN IRISH AND SERBO-CROAT NARRATIVES
}

\section{Introduction: Colour and culture}

The interaction or intersection of colour (as perceived) and culture (as created) has a long human history, and modern scholarly analyses of the workings of this interaction or intersection extend from the hard edges of the physical sciences (optics, the physics of light) to medicine (neurology and ophthalmology) and on across the investigatory spectrum to areas that will most strictly concern us here, such as researches into the symbolic "loading" or coding of colour - that is, investing tint or colour (a refraction of light, received and "decoded" by the human eye) with sometimes powerful affective and symbolic connotations. ${ }^{1}$ By the "symbolic" act I mean the investing of physical data, the perceptible or sensible world, with an additional and extended significance - and here we may take our preview back to prehistory, where the discovery of Neanderthal burials with traces of red ochre spread over the remains of the dead seems to point to an arguably "spiritual" interpretation; the invention of the symbolic (the "live" colour red representing, perhaps, a hope of life after death?) here might equal the attainment of the fully human state - as much so, we might say, as the mechanical discovery and use of tools.

Anthropology, a social science, has brought us some important data from various cultures - from, in fact, many of the symbolic flights of the socalled "savage mind". For a few examples, the Pararé Indians of Amazonia construct a neatly bipolar chromatic-cosmological scheme: here the colour red (that is, in this view, the sign of the true human) exists or is set into a context or surround of "natural" green. ${ }^{2}$ Another study of aboriginal or indigenal symbolism centres on the Campas tribal complex of east-

${ }^{1}$ For two scientific studies of colour, see Tilley 2000, and Mellon \& Sharpe 1983.

${ }^{2}$ Dumont 1976: 32. Dumont's monograph is partially entitled Under the Rainbow. 
ern Peruvian Amazonia, and it discovers that for this group the natural "green" world is inhabited by the "red" (for the Campas themselves, identified as "We"), the "brown" (other - non-Campas - indigenes, identified as "They") and the "white" (these are Peruvians living in the hostile mountains to the west, supernatural beings found in cold lakes, the absolutely "Other") (Weiss 1975: 219-588). Here we find the combination of observable reality ("green", nature), differentiation by social affiliation ("Us" on this side, "Them" on the other), and an additional "loading" of symbolic colour (or the eerie non-colour, that is, "white"). ${ }^{3}$

For investigations into that part of humanity characterised by its specific linguistic family relationship - the Indo-European - the matter of colour-coding has been, if not a primary area of concern, an important one, already associated with Georges Dumézil and his associate (but "nonschool" of) scholar-investigators, meaning that some aspect of his theory of Indo-European trifunctionality has been seen and accepted to resonate in the study of significating, symbolic colour. Here we have the early work of Jan de Vries (1942) on "Rood, wit, zvart", and also the researches and statements of Joël Grisward (1983-84) and of Claude Sterckx (1997) and, as well, we have N. J. Allen's $(1987 ; 1994)$ theoretical construction of additional "functional" areas (and his theoretical construction of a Fourth Function will concern us in this paper). Finally, we have Emily Lyle's (2004) novel and complex "Edinburgh Set", with its important colour components. The pre-assumption in all of these studies is that the three original Dumézilian fonctions, among their other marked characteristics, each display or elevate or are marked by a specific symbolic colour: white or gold for the "sovereign" (or sacral) First Function, red for the bloody and heated fonction guerrière or Second Function, and - a much debated point - black, or blue, or green attached to the all-supporting but often suspect or derogated Third Function of health, wealth, sexuality, generation and increase.

With that brief introduction into a complex set of interpretations, I now can turn to two sets of "heroic" narratives within the broad definition of the Indo-European linguistic complex: the Irish, and the Balkan or SerboCroat, and I hope to show the essential similarity - the "family resemblance" - displayed there, particularly in the colours (or combinations of colours) used to describe the warrior-hero in both contexts. I will then turn

\footnotetext{
${ }^{3}$ Note Edmund Leach's (1981: 57) remark in his Culture and Communication. The Logic by which Symbols are Constructed that, in a "global" examination of symbolic colour, "... there do not seem to be any universals" - even in contrasting or symbolically "loading" black and white.
} 
to the chromatism, the colours, tints and hues used to describe the ambiguous figure who in many ways is the opposite of or foil to the hero (though almost invariably designated as an assistant to him), that is, the Tricksterwarrior. I will also have something to say about another (very important) heroic adjunct or associate, his "heroic" mount or warhorse. In fact, this second area of chromatic contrast holds the main part of my argument, for in it we see the cultural uses of what might be called "non-colour" or mixed colour, the utility of the "mythic" matter of mixture or dappling, or projecting the ambiguous, even the "colour not of this world."

There are certain obvious problems attendant on the identification and the deep meaning of colour or chromatic notations set in our two sets of sources: (1) colours in the evidence under consideration are not clearly, understandably (to us) identified and differentiated; (2) the translation of a text may be unclear or faulty - for example, a particular tint is converted into the wrong English (or other) equivalent; (3) the adduced colour is not a precise identification of an observable reality or a "real" chromatic identification, but the result of a poetic convention (because of a required rhyme-scheme or the like); (4) the colour named is random, unimportant, or redundant, inserted as a sort of a casual, unimportant narrative "filler". As an example of (1), we will see that, in the Serbo-Croat and the Irish materials, the colour grey and the colour green are, in many cases, mixed and confused (and as we will also see, I believe that there are reasons for this in terms of the internal operative logic of symbolism).

\section{Red colour: conventions and examples}

The colour red identifies or is conventionally attached to the Dumézilian Second (or Warrior) Function, and this for certain obvious connections and connotations: the chromatism fits with the visible, obvious and dramatic colour of newly shed blood but it also displays (reflects) the fiery heat of the warrior when he is filled with, overwhelmed with "red" battle-rage (Miller 2000: 285). From one major Irish source (Táin Bo Cúailnge, hereinafter the Táin) we can extract the following examples: Fedelm the Prophetess proclaims her stark vision: "I see red, I see crimson" (Cross \& Slover 1936/1988: 144-145) (cf. the repetition of forderg, ruad in the Atchiu forderg forro, atchíu rúad formula, O’Rahilly 1984: 6-7, 1l. 205, 210, 215, etc.); the fierce warrior Fer Diad's "ruddy countenance" (Cross \& Slover 1936/1988: 214; drechdeirg, O’Rahilly 1984: 75, 1. 2742) is described, Cú Chulainn (Fer Diad's heroic foe) is seen as a "red-sworded hero" (Cross \& Slover 1936/1988: 216; claidebderg, O’Rahilly 1984: 78, 1. 2844-45; cf. also 
"Colba of the red sword", Colba chlaidebdeirg, ibid., 97, 1. 3516); or the "red-mouthed war-goddess" (Cross \& Slover 1936/1988: 231; Baidbi béldergi, O’Rahilly 1984: 95, 1. 3431). We also have, in 1.4318 of the narrative, the interesting description of a warrior in a "dark-red soldier's tunic" (donderg míleta, O'Rahilly 1984: 119), that is, a sort of military uniform is suggested - however anachronistic this may appear. ${ }^{4}$ And finally, we note a "demonic" red-headed and freckled fighter here, "with his variegated - bre$c c$ - mantle and a grey shield" (Cross \& Slover 1936/1988: 260; bratt brecc imme, scíath glass fair, O’Rahilly 1984: 124, 1. 4505).

In other Irish sources we find a fair scattering of red-hued characters and nomenclature: Dagda's son Bodb Derg in The Fate of the Children of Tuirenn (Cross \& Slover 1936/1988: 53), or Luchta Red-Hand in The Wooing of Etain (ibid., 79). In The Burning of Da Derga's Hostel (hereinafter $T B D D$ ) we not only have the hostel-keeper's own name (Da Derga or "Two Reds"), but a primary sign of an approaching fatality is shown here in the appearance of the Three Reds (Trí Deirg, Knott 1936: 16, 1. 526), these sinister figures red even to eyes and teeth; and we note their fitting speech, as they grimly foretell "destruction of life, sating of ravens, feeding of crows, strife of slaughter, whetting of sword-edge" (móra aird airdbe as saegal, sásad fiach, fothath m-bran, bresal airlig, ar-liachtait faebair, Knott 1936: 10, 11. 329-331) and so on (Cross \& Slover 1936/1988: 101). Otherwise, we have the Three Red Hounds of Cualu, outlaws hell-bent on havoc and rapine, leading a crew of uncontrolled madmen (ibid., 104) (OIr. in Stokes 1901). Furthermore, we also have three more figures, that is the Three Champions from the Fairy-Mounds whose red colour, I have surmised elsewhere, was a punishment put on them because they "wrought falsehood" in the side-forts, and so lost their identifying Otherworld green colour (see Miller 2000: 292) until their punishment might be ended (text in Cross \& Slover 1936/1988: 122).

In some early Irish narratives we have, as in the tale of "The Wooing of Emer", the super-hero Cú Chulainn, who goes a-wooing wearing a crimson tunic, and carrying a "blood-red" spear and a crimson shield (ibid., 1567: is this a sexual rather than a warlike reference? That is, are love and war conflated here? It seems very likely). The same dramatically red colourscheme is noted for Cú Chulainn in Bricriu's Feast (ibid., 265). In the saga

\footnotetext{
${ }^{4}$ Note, in Scottish Gaelic, the saighdearan dearg or "red soldiers", the Hanoverian regulars or "redcoats" to whom those soldiers recruited into the Scottish Black Watch, Am Freiceadan Dubh, were to be specifically contrasted. Of course, here we might also bring in Vidal-Naquet's (1986: 106-128) idea of "the black hunter", the adolescent Athenian "anti-hoplite".
} 
The Wasting Sickness of Cú Chulainn, the hero, in one verse, is described as "blood-red of anger" (ibid., 192), while in The Story of Mac Dathó's Pig we find "red strength of anger" (ibid., 205). In The Cattle Raid of Regamna a grim description of the fell battle-goddess, the Badb or Morrigu, gives her red eyebrows and a crimson cloak (ibid., 212), while in The Intoxication of the Ulstermen we have a "purple-fisted" (for "red-handed"?) warrior (ibid., 216), while two druids envision what we might expect, "swords of crimson warfare" (ibid., 225). And so on.

By contrast, I will admit, the selection of Serbo-Croat epic-heroic material examined here in my brief sampling is not particularly remarkable for citations of the canonical red warrior-colour. In the huge epical poem Milman Parry collected from the great Bosnian guslar Avdo Međedović (The Wedding of Smailagić Meho; Parry \& Lord 1974) we observe that a hero's eyes fill with blood when he is enraged (ibid., 141), and that a particular, much contested border zone or sandžak (Bihać) not only boasts "blood-stained heroes" (ibid., 189) but is also called "Bihać the bloody", while the great and final confrontation near Buda between the "Turks", the Bosnian begs and pashas and their forces (and the hero Meho), and their Christian enemy (and the hidden "traitor Vizier") is predictably sanguine, as the river Klima fills with "black blood" or "was running with blood" and "was half water and half blood" (ibid., 219). The men following Tale the Fool (whom we will meet again) from Orašać wear red caps and breeches (this is perhaps conventional or formulaic - the Ottoman janissary uniform, we know, featured red breeches). We have a few odd examples: a petition prepared to send to the Sultan is called a "bloody petition" (ibid., 230) - presumably because it is motivated by a desire for vengeance, for condign punishment. Also, why would the hair of long-imprisoned men be described, by the guslar Avdo, as "ruddy" (ibid., 242)?

The various poems associated with the Serbian epic hero Marko Kraljević are slightly more productive of the colour red and its resonances. The hero - Ban Strahinja (Pennington \& Levi 1984: 113) wears "rosered" clothing; another citation refers to the "bloody banners of war" that are passing overhead (a predictive or prophetic red cloud formation) while the Turkish generals (here, they are the enemies of the Christian hero) all wear "red cloaks" (not the signatory Islamic green; ibid., 154, for both). In Low's earlier translation of some of the collected tales in the Marko epos there is a considerable emphasis placed on Marko's bloody nature: he is "a man of blood" who "might even shed blood on his Slava" - his name-day (ibid., 133, 11. 5-6, an observation also repeated on p. 155, 1. 84). A prophecy of violent vengeance extends dramatically to the phrase "his table shall 
swim in blood" (ibid., 134, l. 56), while Marko's old mother, Jerusima, complains that she is "ever washing bloody garments" (ibid., 158, 1. 9).5

\section{From Hero to Trickster: A reconsideration}

As we can see, the two contrastive narrative contexts treat the emblematic colour marking Dumézil's Indo-European Second Function in a variety of ways, and the Irish stories provide us with more examples: red may be a sign of strong emotion (the colour of choler), it may be a badge reflecting personality or of intrinsic nature in one or more warriors, it may be unattached to physicality and appear as purely symbolic and, finally, it is often simply a physical description of the results of warfare or of combat's inevitable bloodshed, though it might be also predictive or identificatory - or adjectival - that is, the colour identifies a weapon grimly crafted and destined to shed blood. ${ }^{6}$ We now come to our second central figure: the Trickster or "marginal" warrior, who often is associated with the hero, but who carries a very different armamentarium of powers and their attached significances.

What is the Trickster's colour? I can suggest that it is, in fact, no-colour - that is, it is grey, or mottled, or dappled, or mixed, or concealed (by dirt or grime or ashes, for example, in the story-type we call un cendrillot) or it is simply Other. ${ }^{7}$ If it is identifiable within the Dumézilian (or post-Dumézilian) Indo-European theoretical framework, I suspect that it would fall into N. J. Allen's ambitious and intriguing Fourth Function, that function that operates in (or is concerned with) what is beyond, or outside of, or sometimes persists in a combination of all of the canonical three functions. Some decades ago, before Allen's first explorations and invocations of his putative Fourth Function began to appear, I happened to investigate the parallels between two characters who appear in the Irish and in the Serbo-Croat epic contexts, that is, Illiach mac Cass in the Táin, and Tale of Orašać as

\footnotetext{
${ }^{5}$ This sounds like a commonplace scene, but it has a fascinating Irish parallel in the "Washer at the Ford" theme, where bloody armour being washed signifies more bloodshed to come: see Gray's (1983: 97-98) notes to the CMT, referring to pp. 84-85, 11. 354ff., and see Cross 1952: D 1812.5.1.1.7*, for more on the "Ford" motif in the Irish narratives.

${ }^{6}$ Descriptions of costume or accoutrements in both sets of narratives tend to emphasize luxe (precious metals, jewels, and so on, and colour only tangentially) but in the SerboCroat accounts this tendency is even more marked; in one description in the Meho epic a heroic costume is said to be "more gold than cloth" (Parry and Lord 1974: 193).

7 Will Sayers (2008: 106, fn. 6) suggests that "the dappled or striped cloak, as distinct from garments with blocks of solid colour, may also be a sign of social inferiority" - but not, I think, in the cases I cite.
} 
Tale shows up in the Meho epos or "song" and elsewhere in the "Border" material (Miller 1983, expanded in Miller 1985). ${ }^{8}$ The grey or grubby colouration and decrepit equipment affected by my two central characters ${ }^{9}$ was, for me, an important and primary marker, and this colouration (or concealed colouration, accompanied by what might be called a blurring of the sharp and prismatic quality and the "sculptural" or marmoreal shaping of the outline of the typical hero) could be found elsewhere in the range of Indo-European heroic tales, especially in the Northern sagas. But before I go on to cite my further evidence for the importance of an ambiguous noncolour in our two narrative traditions, I should briefly point to what we know about Odysseus, the premier warrior/Trickster-figure in the Greek epic tradition and a wily model of Tricksterdom ever after. From Detienne and Vernant on "cunning intelligence" (Detienne \& Vernant 1991: 18) we find (I was delighted to discover) that Odysseus polymètis, 'of many wiles', was also poikilómettis, that is, of a changeable, varied, dappled, even snakelike kind of wiliness (he also is called aiolós, 'shifting in movement').

From the Irish narrative sources we find the specific grey colouration mainly in a description of weapons, but occasionally applied to horses (the most famous of these being Cú Chulainn's magnificent chariot-horse, the Grey of Macha - a horse first mentioned in the Táin as Ech líath (O'Rahilly 1984: 218, 1. 2919). Then, Conchobar's chariot-horses, we see, are "piebaldheaded" (chendbricc, ibid., 168, 1. 1086). As for other animal images, in 1. 2370 we have Cú Chulainn described as a "noble hawk" which sounds formulaic or even banal, but which, as we shall see, connects the Irish hero to a number of Serbo-Croat citations. Back to the hero's horse: in TBDD (Cross \& Slover 1936/1988: 105) are "thrice-fifty dark-grey steeds". Then we have, again in the Táin, "a broad, grey [headed] spear" (Cross \& Slover 1936/1988: 182, 254; lethanglas as derglassad, O’Rahilly 1984: 43, 1. 1584; lethanglass, O'Rahilly 1984: 119, 1. 4309) - these are, in fact, "realistic" descriptions of the appearance of a smithed-iron weapon, and I suspect that the "blue-coloured weapons of battle" in the "Burning" are also meant to describe smithed iron (Cross \& Slover 1936/1988: 100) - and, for that matter, the "broad-green javelins" (Cross \& Slover 1936/1988: 112) in the same fatal adventure-tale. Finally, a "shifting" grey colouration, as well as the red of blood and violence, marks the demonic figure in 1.4509 of the Táin, for he holds a grey shield - and wears a variegated or speckled mantle while in The Intoxication of the Ulstermen we find "a hideous trio", grey-

${ }^{8}$ For another view and interpretation of Iliach, see Sterckx 2002-3.

${ }^{9}$ In fact Illiach is not at all a main player in the $T B C$, whereas Tale is a significant figure in the Meho poem and, often, elsewhere in the Serbo-Croat "border" songs. 
clad, with bright-grey shields (228) ${ }^{10}$ Of course, the climactic and emblematic "grey" figure in the Táin is Illiach, whose appearance is rendered in O'Rahilly's translation as marked by his two "old, decrepit, mangy" horses, with the old warrior carrying a shield that is "rough, dark-coloured" and iron spears that are "gapped, shaky-headed" and grasping a "rough" sword with a grey guard. He has no charioteer, and for a last characteristic "his private parts hung down through the chariot" (Cross \& Slover 1936/1988: 243; lebarthrintall a chlaip triana charpat sís dó, O’Rahilly 1984: 108, 11. 3910-3911).

I saw Illiach's parallel in the Serbo-Croat materials as Tale the Fool, specifically noting Tale's shabby and dirty appearance; his mount (a "mousegrey", mangy horse), his general air of the extreme and the anti-heroic and his magical (Dagda-like) mace that can both kill and free prisoners from their chains (Miller 1983: 220-222). Nothing like Illiach's grotesque nudity (again resembling Dagda's) will be seen in a society as puritanical as the Border Moslem, but Tale does declare his "reversed" awkwardness in proper heroic society by laying a wild claim to the fiancée of the hero Meho. Certainly Tale could stand as a "grey" and grubby anti-hero (of course, he is also set apart by his intelligence - the obverse of his "mad" behaviour). Beyond him, the Serbo-Croat materials are rich in their descriptions of the aghas' horses - as (in the The Wedding of Smailagic Meho, Parry \& Lord 1974) a "dove-grey" horse (ibid., 167), a "piebald" steed (ibid.,170), a "dapple-grey" mount (ibid., 173), another "mouse-grey" stallion (ibid., 191) and more dapple-grey and piebald horses (ibid., 196). In the Marko epos, the battle-horse of note is Marko's own Šarać, the wonderful piebald mount who talks - and who drinks wine like a hero. We also have a "shadow-coated" horse (Pennington \& Levi 1984: 74), a magical, winged grey horse (ibid., 88), a "grey-coated" horse (ibid., 112), a "dapplegrey" mount (ridden by Ban Strahinja, whose horse is described in another passage as "falcon-grey", ibid., 126). By and large a grey warhorse is more likely to be ridden by a Border hero than any other colour (and the importance of the mount is surely emphasised in the proud description of a warlike hosting: "all on horseback, not a single man on foot") (Parry \& Lord 1974: 183). The other animals whose grey colour is particularly marked are the wolf and the hawk; the former may be associated with a hero's rage (his hair becomes wolflike, bristling: Parry \& Lord 1974: 143, and we see the same usage in a Marko tale, Low 1922/1968: 51). The image of the

${ }^{10}$ Immediately after this passage in the "Intoxication" Dagda makes his entrance - dressed in grey, and with other characteristics - his strange club, his appetites (including sexual desire) and his general persona, all seem to qualify him as a divinity reflective of disorder and "difference", much like Illiach mac Cass. 
hawk or falcon is often used as an image of the hero, but in either case it also may be interpreted as a mysterious or eerie bird, a sign of fatality and doom (Pennington \& Levi 1984: 15, 17). Of course the grey colouration of these two totemic animals is more or less "natural", but at the same time the combination of a wild or raptor sign, and the heroic persona, and a colour (grey) is, I think, significant for our purposes.

\section{A Chromatic Conclusion}

The colour red, taken here as a Second or Warrior Function, IndoEuropean marker in the two contexts under examination, might be expected to be a significant chromatism in any traditional warrior society, of whatever linguistic family or context - it is simply, in my opinion, more likely to appear in the Indo-European cultural mix, where the Second Function often seems to act as a "pivotal" fonction (as the I.-E. trifunctional system itself appears or is often called on in what we might term a "default" mode, available or triggered in dramatic instances, or in formal and ceremonial, emphatic or "intensified" settings - and examples of this are not at all difficult to find). The ambiguous colour grey (or dappling, mixing, a blurred tint or uncertain in colouration) poses another problem entirely. I think that the frequency and importance of the grey-coloured warhorse is partially explained by one entry in the Táin, where Cú Chulainn states (O'Rahilly 1984: 324, 1. 3157) that his and Fer Diad's horses come from the Fomoire, that is, from a foreign, exoteric, or supernatural source - these are "monstrous" animals who can speak (or, like Marko's great piebald horse, speak and drink wine like a hero, or like Uncle Momčilo's grey horse in the Serbian epos, are winged, and can fly) (Pennington \& Levi 1984: 88). I should also note Michael Enright's (2007: 117) important suggestion that the coming of the Iron Age introduced, with a new technology, the novel chromatism of a "raw and remorseless" metal, to which we might add that its grey colour of smithed iron (though perhaps called green, or even blue) was simply added onto the general affect of the "non"-colour, so, in the remarkable creative voice of a gifted singer, deadly weapons that is, swords - could be powerfully imaged as "like dusky snakes" (Parry \& Lord 1974: 182). But our two contexts, Celtic and Slavic, again display the products of a joint, inherited (in my view) Indo-European vision or imagination in which chromatism (the warrior's red, the Trickster-warrior's grey or motley) marks off an important set of players - or, in fact, deeply colours them and their emblematic deeds. ${ }^{11}$

11 The citations made here to supernatural or "wonder" horses of course only scratches the surface of a very large body of material. For the horse considered in the Indo-European 
References

Allen, N. J., 1987: 'The Ideology of the Indo-Europeans: Dumézil's Theory and the Idea of a Fourth Function', in: International fournal of Moral and Social Studies, 2.1, 23-39.

Allen, N. J., 1996: 'Romulus and the Fourth Function', in: Polomé, E., ed., IndoEuropean Religion after Dumézil, fI-ES Monograph series, 16, 13-36.

Cross, T. P., 1952: Motif-Index of Early Irish Literature, Indiana University Publications, Folklore Series, 7. Bloomington: Indiana University Press.

Cross, T. P., \& Slover, C. H., EDS., 1936/1988: Ancient Irish Tales, Totowa, NJ., Barnes \& Noble.

De VRIES, J., 1942: 'Rood, wit, zwaart', in: Volkskunde 1, 1-10.

Detienne, M., \& Vernant, J.-P., 1991: Cunning Intelligence in Greek Culture and Society, transl. by J. Lloyd, Chicago: University of Chicago Press.

Dumont, J.-P., 1976: Under the Rainbow: Nature and Supernature among the Parare Indians, Austin: University of Texas Press.

EnRIght, M. L., 2007: 'Ritual and Technology in the Iron Age: An Initiation Scene in the Gundestrup Cauldron', in: Glosecki, S. O., ed., Myth in Early Northwest Europe, Medieval and Renaissance Texts and Studies, 320 (Arizona Studies in the Middle Ages and the Renaissance, 21), Tempe, AZ: ACMRS, 105-120.

Gray, E. A., ED., 1995: Cath Maige Tuired. The Second Battle of Mag Tuired, Irish Texts Society Main Series 52, Dublin: Irish Texts Society.

GRISWARD, J., 1983-84: 'L'arbre blanc, vert, rouge de la Quête du Graal et le symbolisme colouré des Indo-Européens', in: Ogam: tradition celtique. Etudes indo-européens, t. 35-36, fasc. 1, 111-124.

KnotT, E., ED., 1936: Togail Bruidne Da Derga, Mediaeval and Modern Irish Series, 8, Dublin: Dublin Institute for Advanced Studies (repr. 1963, 1975).

LEACH, E. R., 1981: Culture and Communication: The Logic by Which Symbols Are Connected, Themes in the Social Sciences, Cambridge: Cambridge University Press.

Low, D. H., TRANSL., 1922/1968: The Ballads of Marko Kraljević, Westport, CT: Greenwood Press.

context see Puhvel 1970: 159-172, on "Aspects of Equine Functionality". In Scottish lore we find the kelpy or "water-horse" and in Tom Peete Cross's Motif-Index see section B181, "Magic Horse" (63) with a large group of citations referring to "Magic horses from the water-world". And, for later folk-reflexes of the legend of the extraordinary horse, see the fifteenth-sixteenth century tales of An Gille Deacair ("The Hard Lad") or Bodach an Chóta Lacchtna ("The Grey-Coated Churl" - grey again!), anti-heroes who "often ride what appears to be an old wornout horse that turns out to be very fast". See e.g. Mac Piarais 1936, also Watson 1979. I am very grateful to Séamus Mac Mathúna for bringing these extensions of the "horsed anti-hero" in a later Irish context to my attention. 
Lrle, E., 2004: 'Which Triad? A Critique and Development of Dumézil's Trifunctional Theory', in: RHR 221, 5-21.

Mac Piarais, P., ED., 1936: Bodach an Chóta Lachtna, Baile Âtha Cliath.

Mellon, J. D., \& SharPe, L. T., EDS., 1983: Colour Vision: Physiology and Psychophysics, New York: Academic Press.

MilleR, D. A., 1983: 'The Blackened Hero: Serbian and Celtic Evidence for the Warrior of Reversal', in: The Mankind Quarterly, 24.2, 219-229.

MilLER, D. A., 1985: 'Blackened Hero and Heroic Trickster: An Investigation of Congeners', in: The Mankind Quarterly, 26.1-2, 99-110.

Miller, D. A., 2000: The Epic Hero, Baltimore and London: The Johns Hopkins University Press.

O’Rahilly, C. O., ED., 1984: Táin Bó Cuailnge from the Book of Leinster, Dublin: Dublin Institute for Advanced Studies.

ParRY, M., \& Lord, A., Coll. AND TRANSL., 1974: The Wedding of Smailagić Meho, Serbo-Croat Heroic Songs, III, Cambridge, MA: Harvard University Press.

Pennington, A. \& Levi, P., transl., 1984: Marko the Prince. Serbo-Croat Heroic Songs, New York: St. Martin's Press.

Punvel, J., 1970: 'Aspects of Equine Functionality', in: Puhvel, J., ed., Myth and Law Among the Indo-Europeans, Studies in Comparative Mythology. Berkeley/Los Angeles/London: The University of California Press, 159-172.

SAYERS, W. S., 2008: 'Deficient Royal Rule: the King's Proxies, Judges, and the Instruments of his Fate', in: Wiley, D., ed., Essays on the Early Irish Kings, Dublin: Four Courts Press, 104-126.

SterCKX, C., 1997: 'Le roi blanc, le roi rouge et le roi bleu', in: ZCP 49-50, 837-846.

SterckX, C., 2002-3: 'Iliach mac Cais', in: Ollodagos 17, 159-163.

StoKEs, W., ED. AND tRANs., 1901: 'The Destruction of Da Derga's Hostel', in: Revué Celtique, 22, 9-61, 165-215, 282-329, 390-437.

Tilley, R. J. D., 2000: Colour and Optical Properties of Materials: an Exploration of the Relationship between Light, the Optical Properties of Materials, and Colour, Chichester: John Wiley \& Sons.

VIDAL-NAQUET, P., 1986: The Black Hunter. Forms of Thought and Forms of Society in the Greek World, transl. by A. Szegedy-Marszak, Baltimore/London: The Johns Hopkins University Press.

Watson, S., ED., 1979: Mac na Michomhairle, Baile Átha Cliath: An Clóchomhar.

WeIss, G., 1975: 'Campa Cosmology: The World of a Forest Tribe in South America', in: Anthropological Papers of the American Museum of Natural History, 52.5, 219-588. 


\title{
Boje slave i boje prijevare: junak i njegov protivnik u irskim i srpsko-hrvatskim pričama
}

\begin{abstract}
Sažetak
Nakon kratkog uvoda koji daje općeniti, teoretski pogled na "boju kao simbol", ovaj se rad bavi određenim vidovima indoeuropske simboličke palete (usp. rano djelo Jana de Vriesa) i novijim istraživanjima koja su proveli Joël Grisward, Nick Allen i Emily Lyle. Naglasak je ovdje na "hrabrom" junaku kakav je predstavljen u srpsko-hrvatskim junačkim pjesmama (konkretno guslar Smailagić Meho Avde Međedovića) i u likovima Cú Chulainna i drugih (npr. Fer Diad) u Táinu. Boja se koristi za dojam, da pokaže ili pobudi osjećaje. Boja se koristi i samo kao ukras, a može se govoriti i o poetskoj (formulaičnoj) ulozi boje. Druga je tema boja Prevaranta, na primjeru priče Budalin u srpsko-hrvatskim materijalima i Iliacha mac Cassa u Táinu (s usputnim pogledom na irski Dagda i neke norveške dokaze). Zanimljiva je ne-boja (jednoličnost, šarenilo i raznobojnost), simboličko značenje sive boje kao prijetvorne, zavaravajuće, zlokobne, natprirodne i u svakom drugom smislu anti-junačke (pogotovo kao oznaka dobi) - možda bi se mogla rekonstruirati "drama suprotnosti" u živim bojama. U zaključku se skreće pozornost na simbolički spektar boja i njihovih značenja koja se nalaze u ova dva indoeuropska konteksta.
\end{abstract}

Ključne riječi: irske junačke priče, srpsko-hrvatske junačke priče, znakovite boje, junak i njegov protivnik

Key words: Irish hero-tales, Serbo-Croat hero-tales, significant colours, Hero and Trickster 